\title{
SURAT KUASA DAN GUGATAN (ANALISIS KONSEP DAN TEKNIK PENULISAN)
}

\author{
Syahrul Sitorus
}

Sekolah Tinggi Agama Islam Sumatera Medan

Jl. Sambu No. 64, Kota Medan, Sumatera Utara

e-mail: syahrulsitorus72@gmail.com

\begin{abstract}
Abstrak: Surat Kuasa dan Gugatan merupakan dua hal yang tidak dapat dipisahkan ketika seorang Advokat menjalankan profesinya untuk membela kepentingan hukum kliennya, khususnya dalam perkara perdata di pengadilan, sehingga dapat dikatakan kedua hal tersebut merupakan jantung dari penanganan perkara perdata. yang harus dipahami oleh seorang Advokat. Dalam menyusun surat kuasa dan gugatan seorang Advokat dituntut untuk memahami hukum formal dan material dari perkara yang ditanganinya, selain itu Advokat dituntut untuk memahami konstruksi hukum perkara yang ditangani oleh seorang Advokat, tanpa pemahaman. Di atas sangat sulit untuk menarasikan berita acara surat kuasa dan gugatan dalam kasus tersebut. Pengertian dalam menyusun surat kuasa dan gugatan merupakan modal dasar seorang calon Advokat sebelum menjalankan profesi Advokat, sehingga Organisasi Advokat menjadikan hal tersebut sebagai objek pemeriksaan bagi calon Advokat dalam Ujian Profesi Advokat untuk menilai apakah calon Advokat tersebut layak. memenuhi syarat untuk diangkat menjadi Advokat yang diangkat sebagai Advokat oleh Organisasi Advokat namun tidak dapat menyusun surat kuasa dan gugatan, tentunya hal ini sangat merugikan masyarakat pencari keadilan pada umumnya.
\end{abstract}

Kata Kunci: Surat kuasa, Surat Gugatan, Advokat

Abstract: Power of attorney and lawsuit are two things that are inseparable when an Advocate carries out his profession to defend the legal interests of his client, especially in civil cases in court, so it can be said that these two things are the heart of handling civil cases that an Advocate must really understand. In formulating a power of attorney and a lawsuit an Advocate is required to understand the formal and material laws of the case he is handling, in addition to that Advocates are required to understand the legal construction of the case being handled by an Advocate, without understanding the above it is very difficult to narrate the minutes of the power of attorney and lawsuit in the said case. Understanding in formulating a power of attorney and lawsuit is the basic capital of a prospective Advocate before carrying out the Advocate profession, so that the Advocate Organization makes this an object of examination for prospective Advocates in the Advocate Professional Exam to assess whether the prospective Advocate is eligible to be appointed as an Advocate being appointed as an Advocate by the Advocate Organization but unable to formulate a power of attorney and lawsuit, of course this is very detrimental to the justice-seeking community in general.

Keywords: Representative letter, Lawsuit, Advocate 


\section{PENDAHULUAN}

Membuat surat kuasa khusus dan gugatan tidaklah semudah yang dibayangkan orang, bisa dikatakan dalam penyusunan kedua surat tersebut gampanggampang sukar. Akan dikatakan gampang atau mudah jika yang menyusun surat kuasa khusus dan gugatan adalah orang yang sudah ahli dan berpengalaman, tetapi sukar bagi mereka yang bukan seorang ahli. Jangankan bagi orang awam di bidang hukum, para Sarjana Hukum yang pekerjaan sehari-harinya sebagai Advokat/Pengacara pun, seringkali mengalami kesulitan dalam membuat surat kuasa khusus dan gugatan, maka oleh karena itu salah satu bahagian dari materi Ujian Profesi Advokat (UPA) Perhimpunan Advokat Indonesia (PERADI) bagi para sarjana yang berlatar belakang Pendidikan Tinggi Ilmu Hukum yang telah selesai mengikuti Pendidikan Khusus Profesi Advokat (PKPA) PERADI yang hendak terjun ke dunia profesi Advokat/Pengacara adalah mengenai teknik menyusun surat kuasa khusus dan gugatan perbuatan melawan hukum (PMH) atau wanprestasi (WP).

\section{SURAT KUASA}

Kuasa hukum menurut Pasal 1792 KUH Perdata berbunyi “ Pemberian kuasa adalah suatu persetujuan dengan mana seorang memberikan kekuasaan kepada seorang lain yang menerimanya untuk dan atas namanya menyelenggarakan suatu urusan". Jika dicermati secara mendalam maka dalam Pasal 1792 KUH Perdata tersebut terdapat kata "persetujuan" yang dapat dimaknai sebagai "perjanjian" oleh karena itu pemberian kuasa adalah perjanjian kuasa. Dengan demikian dalam surat kuasa dapat diperjanjikan hal-hal yang berkaitan dengan hak dan kewajiban antara pemberi kuasa dengan penerima kuasa, misalnya mengenai hak retensi, kuasa subsititusi dan pencabutan surat kuasa. Itu sebabnya Pasal 1792 KUH Perdata maupun Pasal 1793 Ayat (1) KUH Perdata menyatakan, pemberian kuasa selain didasarkan atas persetujuan kedua belah pihak, dapat dituangkan dalam bentuk akta otentik atau akta di bawah tangan maupun dengan lisan. Namun demikian, tanpa mengurangi penjelasan di atas, berdasarkan Pasal 1793 Ayat (2) KUH Perdata, penerimaan kuasa dapat terjadi secara diam-diam. Akan tetapi, cara diamdiam ini, tidak dapat diterapkan dalam pemberian kuasa khusus. Kuasa khusus harus disepakati secara tegas dan harus dituangkan dalam bentuk akta atau surat kuasa khusus.

Pasal 1 angka (1) UU No. 18 tahun 2003 tentang Advokat menyebutkan, Advokat adalah orang yang berprofesi memberi jasa hukum, baik di dalam maupun di luar pengadilan yang memenuhi persyaratan berdasarkan Undang-Undang ini. (Peradi, 2007). Advokat dalam memberikan jasa pelayanan hukum terhadap klien yang membutuhkan bantuan hukum tentunya didasarkan atas persetujuan kedua belah pihak yang dituangkan kemudian dalam bentuk surat kuasa khusus. Dalam menyusun surat kuasa 
khusus setidaknya harus tercantum 19 komponen, yakni:

1. Mencantumkan Judul: Surat Kuasa Atau Surat Kuasa Khusus.

2. Memuat identitas Pemberi Kuasa (nama dan alamat yang jelas).

3. Menyebutkan : sebagai Pemberi Kuasa.

4. Menegaskan pilihan domisili hukum pemberi kuasa (Kantor Advokat yang ditunjuk).

5. Menyebutkan Nama Penerima Kuasa (dalam kasus ada 2 orang Advokat).

6. Menegaskan dari mana Penerima Kuasa (sebagai Advokat dari kantor apa).

7. Penegasan tentang : bertindak bersamasama atau masing-masing sendiri.

8. Menyebutkan sebagai PENERIMA KUASA.

9. Penyebutan kata KHUSUS.

10. Tentang tujuan Pemberian Kuasa (untuk mewakili Pemberi Kuasa mengajukan Gugatan).

11. Identitas Tergugat (nama dan alamat).

12. Tentang Kasus Apa (tidak menjalankan isi perjanjian).

13. Pengadilan Negeri mana Gugatan tersebut diajukan.

14. Mengajukan Hak Subtitusi.

15. Mencantumkan Hak Retensi.

16. Tanggal Pemberian Kuasa.

17. Kolom nama dan tanda tangan Pemberi Kuasa.

18. Kolom nama dan tanda tangan Penerima Kuasa.

19. Penempatan Materai (Materai 6000).

\section{GUGATAN}

Dalam mengajukan gugatan HIR dan R.Bg hanya mengatur tentang cara mengajukan gugatan, sedangkan persyaratan mengenai format gugatan, isi gugatan HIR dan RBG tidak ada mengatur. Namun sekedar persyaratan standar mengenai isi gugatan dapat dilihat dalam Pasal 8 Angka 3 RV yang mengisyaratkan agar sebuah gugatan memuat: (1). Identitas para pihak; (2). Dalil-dalil konkrit tentang adanya hubungan hukum di mana dalam perjalanan hubungan hukum tersebut terjadi "peristiwa hukum" baik peristiwa hukum karena perbuatan melawan hukum maupun peristiwa hukum karena wanprestasi; dan (3). Petitum atau tuntutan. (Lemek, 1993). Dalam praktek surat gugatan setidaktidaknya harus memuat 21 komponen, yakni :

1. Surat gugatan ditujukan kepada Pengadilan Negeri tempat gugatan diajukan.

2. Materi Gugatan tentang: Wan Prestasi atau Perbuatan Melawan Hukum.

3. Identitas Advokat yang mengajukan Gugatan.

4. Dasar hukum kuasa mengajukan Gugatan (Surat Kuasa khusus dari Klien)

5. Penyebutan sebagai Penggugat.

6. Identitas Tergugat (Nama dan Alamat lengkap).

7. Penyebutan sebagai Tergugat.

8. Dasar Hukum dari Gugatan (Surat Perjanjian atau kontrak yang mengatur Hubungan antara Penggugat Dan Tergugat).

9. Perbuatan apa yang tidak dilakukan oleh Tergugat sehingga Tergugat dapat dianggap telah melakukan Wan 
Hikmah, Vol. 17, No. 2, Juli - Desember 2020, p-ISSN:1829-8419 e-ISSN: 2720-9040

Prestasi atau Perbuatan Melawan Hukum.

10. Memuat perbuatan Tergugat telah menimbulkan kerugian bagi Penggugat.

11. Memuat perbuatan Tergugat telah menimbulkan kerugian bagi Penggugat ditambah bunga dan keuntungan lainnya yang diharapkan.

12. Adanya Permohonan Sita Jaminan.

13. Petitum yang menyatakan menerima dan mengabulkan Gugatan Penggugat untuk seluruhnya.

14. Petitum yang menyatakan Perjanjian antara Penggugat dan Tergugat adanya Sah dan Mengikat.

15. Petitum putusan yang menyatakan Tergugat telah melakukan Wan Prestasi atau Perbuatan Melawan Hukum.

16. Petitum menyatakan sita jaminan yang telah diletakkan tersebut di atas sah dan berharga

17. Petitum menghukum kepada Tergugat untuk membayar atau melaksanakan kewajibannya.

18. Petitum yang menyatakan putusan dalam perkara ini dapat dijalankan terlebih dahulu walaupun ada upaya hukum banding, kasasi dan peninjauan kembali dari Tergugat.

19. Petitum Tentang beban Biaya Perkara kepada Tergugat.

20. Permohonan untuk Putusan yang seadil-adilnya.

21. Kolom nama dan tandatangan Kuasa Penggugat.
PERBUATAN MELAWAN HUKUM DAN WAN PRESTASI

\section{Perbuatan Melawan Hukum (PMH)}

Sekadar menyegarkan ingatan, Perkara Perdata antara Lindenbaum melawan Cohen adalah suatu tonggak penting yang memperluas pengertian perbuatan melawan hukum (onrechtmatige daad). Perkara tersebut melibatkan dua kantor percetakan yang saling bersaing, satu milik Lindenbaum dan satu lagi milik Cohen. Suatu hari, pegawai yang bekerja di kantor Lindenbaum dibujuk oleh Cohen agar memberitahukan nama-nama pelanggannya berikut penawaran yang diberikan kepada mereka. Dengan data itu, Cohen bisa memanfaatkan data-data tersebut untuk membuat suatu penawaran baru yang akan membuat orang-orang akan memilih kantor percetakannya dari pada kantor Lindenbaum. Untungnya, perbuatan Cohen cepat diketahui oleh Lindenbaum. Akibatnya, Lindenbaum langsung mengajukan gugatan terhadap Cohen di muka pengadilan Amsterdam. Selain mengajukan gugatan perbuatan melawan hukum terhadap Cohen, Lindenbaum juga meminta ganti rugi atas perbuatan Cohen tersebut. Di tingkat pertama Cohen kalah, tetapi sebaliknya di tingkat banding justru Lindenbaum yang kalah. Di tingkat banding, dikatakan bahwa tindakan Cohen tidak dianggap sebagai suatu perbuatan melawan hukum karena tidak dapat ditunjukkan suatu pasal dari UndangUndang yang telah dilanggar oleh Cohen. Akhirnya melalui putusan Hoge Raad (Mahkamah Agung Belanda) tanggal 31 Januari 1919, Lindenbaum lah yang 
dinyatakan sebagai pemenang. Hoge Raad menyatakan bahwa pengertian perbuatan melawan hukum di Pasal 1401 BW, termasuk pula suatu perbuatan yang melanggar hak-hak orang lain, bertentangan dengan kewajiban hukum si pelaku, atau bertentangan dengan kesusilaan. Sebelum adanya Arrest tersebut, pengertian perbuatan melawan hukum, yang diatur pada Pasal 1365 KUHPerdata (Pasal 1401 BW) hanya ditafsirkan secara sempit. Yang dikatakan perbuatan melawan hukum adalah tiap perbuatan yang bertentangan dengan hak orang lain yang timbul karena UndangUndang (onwetmatig). Orang tidak bisa mengajukan gugatan perbuatan melawan hukum dan meminta ganti kerugian apabila tidak disebutkan secara jelas pasal berapa dan undang-undang mana yang telah dilanggar.

Sebagai contoh lainnya, di Kota Zutphen, Belanda, seorang pemilik rumah yang tinggal di bagian bawah rumah bertingkat pernah mengajukan gugatan perbuatan melawan hukum terhadap pemilik rumah yang tinggal di bagian atas. Penyebabnya, barang-barang yang berada ruangan di bagian bawah menjadi rusak karena pemilik rumah di bagian atas menolak untuk menutup kerannya. Akibat musim dingin, pipa saluran air di bagian bawah pecah, sehingga ketika pemilik rumah yang di atas menyalakan keran, justru yang dibagian bawah menjadi kebanjiran. Ketika itu, gugatan perbuatan melawan hukum tersebut ditolak karena tiada pasal dari suatu Undang-Undang yang mengharuskan pemilik rumah bagian atas untuk mematikan kerannya.Yang pasti, KUHPerdata memang tidak mendefinisikan dan merumuskan perbuatan melawan hukum. Perumusannya, diserahkan kepada doktrin dan yurisprudensi. Pasal 1365 KUH Perdata hanya mengatur barang siapa melakukan perbuatan melawan hukum harus mengganti kerugian yang ditimbulkannya. Belanda yang telah memasukkan Arrest Hoge Raad 31 Januari 1919 menjadi salah satu pasal dalam BWnya. Perumusan dan batasan perbuatan melawan hukum sudah sedemikian luas di “ negeri kincir angin “ ini. (prinsts, 1996).

\section{Wan Prestasi (WP)}

Istilah wanprestasi berasal dari bahasa Belanda yang berarti prestasi buruk. Wanprestasi dapat berupa tidak melaksanakan apa yang diperjanjikan, melaksanakan yang diperjanjikan tapi tidak sebagaimana mestinya, melaksanakan apa yang diperjanjikan tapi terlambat, melakukan sesuatu yang menurut perjanjian tidak boleh dilakukan.

Pakar hukum pidana Yahya Harahap mengartikan wanprestasi dengan pelaksanaan kewajiban yang tidak tepat pada waktunya atau dilakukan tidak menurut selayaknya. Pihak yang merasa dirugikan akibat adanya wanprestasi bisa menuntut pemenuhan perjanjian, pembatalan perjanjian, atau meminta ganti kerugian pada debitur. Ganti kerugiannya bisa meliputi biaya yang nyata-nyata telah dikeluarkan, kerugian yang timbul akibat wanprestasi tersebut, serta bunga. Pengertian bunga di sini adalah hilangnya keuntungan yang sudah diperkirakan atau dibayangkan oleh kreditur seandainya tidak 
terjadi wanprestasi. Kewajiban debitur untuk membayar ganti rugi tidak serta merta timbul pada saat dirinya lalai. Karena itu, harus ada pernyataan lalai terlebih dahulu yang disampaikan oleh kreditur ke debitur (Pasal 1238 jo Pasal 1243 KUHPerdata). Untuk menghindari celah yang mungkin bisa dimanfaatkan debitur, ada baiknya kreditur membuat secara tertulis pernyataan lalai tersebut atau bila perlu melalui suatu peringatan resmi yang dibuat oleh juru sita pengadilan.

\section{Perbedaan Perbuatan Melawan Hukum (PMH) dan Wan Prestasi (WP)}

Orang sering mencampuradukkan antara gugatan wanprestasi dan gugatan perbuatan melawan hukum. Adakalanya, orang mengajukan gugatan perbuatan melawan hukum. Namun dalam dalil-dalil yang dikemukakan, sebenarnya lebih tepat kalau diajukan gugatan wanprestasi. Ini akan menjadi celah yang akan dimanfaatkan tergugat dalam tangkisannya.

Membedakan antara perbuatan melawan hukum dan wanprestasi sebenarnya gampang-gampang susah. Sepintas lalu, kita bisa melihat persamaan dan perbedaanya dengan gampang. Baik perbuatan melawan hukum dan wanprestasi, sama-sama dapat diajukan tuntutan ganti rugi.

Sementara perbedaannya, seseorang dikatakan wanprestasi apabila ia melanggar suatu perjanjian yang telah disepakati dengan pihak lain. Tiada wanprestasi apabila tidak ada perjanjian sebelumnya. Sedangkan seseorang dikatakan melakukan perbuatan melawan hukum apabila perbuatannya bertentangan dengan hak orang lain atau bertentangan dengan kewajiban hukumnya sendiri, atau bertentangan dengan kesusilaan.

Beberapa sarjana hukum bahkan berani menyamakan perbuatan melawan hukum dengan wanprestasi dengan batasanbatasan tertentu. Asser Ruten, Sarjana Hukum Belanda, berpendapat bahwa tidak ada perbedaan yang hakiki antara perbuatan melawan hukum dan wanprestasi. Menurutnya, wanprestasi bukan hanya pelanggaran atas hak orang lain, melainkan juga merupakan gangguan terhadap hak kebendaan. Senada dengan Rutten, Yahya Harahap berpendapat bahwa dengan tindakan debitur dalam melaksanakan kewajibannya yang tidak tepat waktu atau tak layak, jelas itu merupakan pelanggaran hak kreditur. Setiap pelanggaran hak orang lain berarti merupakan perbuatan melawan hukum. Dikatakan pula, wanprestasi adalah species, sedangkan genusnya adalah perbuatan melawan hukum.

Selain itu, bisa saja perbuatan seseorang dikatakan wanprestasi sekaligus perbuatan melawan hukum. Misalnya A yang sedang mengontrak rumah $\mathrm{B}$, tidak membayar uang sewa yang telah disepakati. Selain belum membayar uang sewa, ternyata $\mathrm{A}$ juga merusak pintu rumah $\mathrm{B}$.

Namun apabila kita cermati lagi, ada suatu perbedaan hakiki antara sifat perbuatan melawan hukum dan wanprestasi. Bahkan, Pitlo menegaskan bahwa baik dilihat dari sejarahnya maupun dari sistematik undang-undang, wanprestasi tidak dapat digolongkan pada pengertian perbuatan melawan hukum. 
Djojodirdjo berpendapat bahwa amat penting untuk mempertimbangkan apakah seseorang akan mengajukan tuntutan ganti rugi karena wanprestasi atau karena perbuatan melawan hukum. Menurut Moegni, akan ada perbedaan dalam pembebanan pembuktian, perhitungan kerugian, dan bentuk ganti ruginya antara tuntutan wanprestasi dan perbuatan melawan hukum. Dalam suatu gugatan perbuatan melawan hukum, Penggugat harus membuktikan semua unsur-unsur perbuatan melawan hukum selain harus mampu membuktikan adanya kesalahan yang diperbuat debitur. Sedangkan dalam gugatan wanprestasi, Penggugat cukup menunjukkan adanya wanprestasi atau adanya perjanjian yang dilanggar. Kemudian dalam suatu gugatan perbuatan melawan hukum, Penggugat dapat menuntut pengembalian pada keadaan semula (restitutio in integrum). Namun, tuntutan tersebut tidak diajukan apabila gugatan yang diajukan dasarnya adalah wanprestasi. (Yahya: 2005:89)

\section{Masalah Simpel}

Setiawan, mantan Hakim Tinggi yang sekarang menjadi Arbiter di BANI melihat perbedaan antara wanprestasi dan perbuatan melawan hukum sederhana sekali. "Bedanya Undang-Undang dengan perjanjian apa sih? Undang-Undang tertulis, perjanjian bisa tertulis bisa tidak tertulis. Cuma Undang-Undang berlaku untuk umum, perjanjian berlaku untuk para pihak," ujarnya kepada hukumonline. Menurut Setiawan, kita berbicara perbuatan melawan hukum kalau melanggar UndangUndang yang berlaku untuk umum.
Sedangkan kita berbicara wanprestasi kalau kita berbicara tentang perjanjian yang berlaku untuk para pihak. "Simpel sekali masalahnya," ungkapnya. Setiawan berpendapat bahwa perbedaan wanprestasi dan perbuatan melawan hukum yang terus dibesar-besarkan seakan-akan menjadi perdebatan klasik yang tidak pernah usai. Hal ini sebenarnya tidak lebih dari upaya salah satu pihak untuk menghindar memenuhi kewajibannya. Setiawan mengemukakan bahwa sekarang ini orang lebih berprinsip kalau bisa tidak bayar atau kalau bisa memperlambat, buat apa bayar sekarang. "Sebenarnya hukum itu kaedahnya cuma dua: sopo sing salah kudu dihukum, sopo sing ngutang kudu bayar (siapa yang salah harus dihukum, siapa yang berhutang harus membayar, red), tidak ada lain. Pada akhirnya semua bermuara ke sana," cetus Setiawan.

Dari uraian di atas, sebelum mengajukan gugatan, ada baiknya calon Penggugat mempertimbangkan terlebih dahulu apakah akan mengajukan gugatan wanprestasi atau perbuatan melawan hukum terhadap lawannya. Seandainya mengajukan gugatan wanprestasi, ia cukup menunjukkan perjanjian yang dilanggar dan Tergugat-lah yang akan dibebani pembuktian untuk menyatakan tidak terjadi wanprestasi. Namun kalau akan mengajukan gugatan perbuatan melawan hukum, Penggugat harus siap-siap untuk membuktikan dan menunjukkan bahwa bukan hanya ada suatu perbuatan melawan hukum, tetapi ada juga unsur kesalahan (schuld) yang dilakukan oleh Tergugat. Mengenai tuntutan ganti rugi yang diminta, 
untuk wanprestasi jumlahnya tentu bisa diperkirakan karena ada dalam perjanjian. Sedangkan untuk perbuatan melawan hukum, diserahkan kepada Hakim untuk menilai besarnya ganti rugi. Jadi, mau mengajukan gugatan wanprestasi atau perbuatan melawan hukum?

Penjabaran 19 Komponen Dalam Surat Kuasa Khusus Dan 21 Komponen Dalam Gugatan Wanprestasi (WP) dan Perbuatan Melawan Hukum (PMH)

\section{Contoh Kasus Wanprestasi}

\section{Ringkasan Kasus Posisi}

PT. Bank Bola Dunia, sebuah bank devisa yang didirikan menurut Hukum Indonesia berdasarkan Akta Pendirian Perseroan Terbatas No. 7 tanggal 06 November 1999 dibuat di hadapan Notaris Teddy Anwar,S.H. berkedudukan di Jakarta Pusat yang telah memperoleh pengesahan dari Menteri Kehakiman No. C-2 12.859. HT.01.01 Tahun 2001, yang berkantor pusat di Jln. Sudirman No. 66 Jakarta Pusat.

Drs. Ali Akbar, selaku Direktur Utama PT. Bank Bola Dunia melalui Akta Perjanjian Hutang Piutang No. 100 tertanggal 01 Februari 2004 yang dibuat di hadapan Notaris Abdul Jalil, S.H. berkedudukan di Jakarta Pusat memberikan Pinjaman Uang sebesar Rp.120 miliar kepada PT. Manca Negara yang berkantor di JI. Sisingamangaraja No. 123 Jakarta Selatan, PT. Manca Negara diwakili oleh Direktur Utama Jhony Malingkas. Pinjaman tersebut dengan waktu pengembalian selama 2 (dua) tahun, dalam Perjanjian Hutang Piutang tertanggal 01
Februari 2004 tersebut PT. Manca Negara telah menyerahkan Jaminan milik PT. Manca Negara berupa : Sebidang tanah seluas 1.000 M2 berikut bangunan di atasnya terletak di JI. Sisingamangaraja No. 123 Jakarta Selatan sebagaimana bukti kepemilikan berupa Sertifikat Hak Milik No. 31.

Sebidang tanah seluas 5.000 M2 berikut bangunan di atasnya terletak di JI. Fatmawati No. 41 Jakarta Selatan sebagaimana bukti kepekmilikan berupa Sertifikat Hak Milik No. 99. Sesuai dengan Akta Perjanjian Hutang Piutang No. 100 yang dibuat di hadapan Notaris Abdu Jalil, SH tersebut PT. Manca Negara harus mengembalikan seluruh Pinjaman kepada PT. Bank Bola Dunia dengan cara mengangsur sebesar Rp. 5 Miliyar setiap bulannya.

PT. Manca Negara hingga 01 Februari 2005 telah berhasil mencicil sebanyak 12 kali angsuran mencapai jumlah Rp. 60 Miliyar akan tetapi setelah itu hingga Perjanjian yang seharusnya berakhir tanggal 01 Februari 2006 PT.Manca Negara tidak pernah mengangsur kewajibannya sehingga sisa kewajibannya sebesar Rp. 60 Miliyar kepada PT. Bank Bola Dunia tidak juga dilunasi.

Segala upaya yang patut menurut hukum telah dilakukan oleh PT. Bank Bola Dunia untuk menagih sisa Hutang PT. Manca Negaratetap tidak berhasil.

Oleh karena itu PT. Bank Bola Dunia bermaksud untuk menggugat PT. Manca Negara dan menunjuk Advokat Agus Purnomo, S.H. dan Albert 
Simorangkir, S.H. dari Kantor Pengacara Agus-Albert \& Rekan yang berkantor di Jln. Antara No. 7 Jakarta Pusat.
Berdasarkan ringkasan kasas posisi tersebut di atas, maka contoh surat kuasa Khusus Wanprestasi.

\section{SURAT KUASA KHUSUS}

Yang bertanda tangan di bawah ini:

Nama

Pekerjaan/Jabatan

Alamat
: DRS.ALI AKBAR

: DIREKTUR UTAMA PT.BANK BOLA DUNIA

: Jln. SUDIRMAN No. 66 JAKARTA PUSAT

Dalam hal ini bertindak untuk dan karena jabatannya selaku Direktur Utama PT. Bank Bola Dunia, untuk selanjutnya disebut sebagai PEMBERI KUASA

Untuk sementara MEMILIH DOMISILI HUKUM DIALAMAT KUASANYA

Dengan ini memberi kuasa kepada: AGUS PURNOMO, S.H. DAN ALBERT SIMORANGKIR,S.H. Advokat dari KANTOR PENGACARA AGUS-ALBRET DAN REKAN yang berkantor di Jln.Antara No. 7 Jakarta Pusat BAIK BERSAMA MAUPUN MASING-MASING SENDIRI

Untuk selanjutnya disebut PENERIMA KUASA

K H U S U

Bertindak untuk dan atas nama serta mewakili Pemberi Kuasa PT.Bank Bola Dunia UNTUK MENGAJUKAN GUGATAN terhadap PT. MANCA NEGARA yang beralamat di Jl.Sisingamangaraja No.123 Jakarta Selatan, yaitu tidak melaksanakan Perjanjian Pengembalian Pinjaman berdasarkan AKTA PERJANJIAN HUTANG PIUTANG yang dibuat di hadapan Notaris Abdul Jalil, SH dengan Akta No. 100 tertanggal 01 Februari 2004 melalui kepaniteraan PENGADILAN NEGERI JAKARTA SELATAN.

Selanjutnya kepada Penerima Kuasa diberikan segala hak untuk melakukan tindakan hukum yan dianggap perlu dan berguna untuk kepentingan Hukum Pemberi Kuasa selaku Penggugat.

Kuasa ini diberikan dengan HAK SUBSTITUSI dan HAK RETENSI

JAKARTA, 15 FEBRUARI 2014

PEMBERI KUAS A

PENERIMA KUASA

Meterai 6000

DRS. ALI AKBAR

AGUS PURNOMO,S.H. 


\section{Contoh Gugatan Wanprestasi}

Jakarta 17 Februari 2014

Kepada Yth

Ketua Pengadilan Negeri Jakarta Selatan

Jln. Ampera Raya No. 136

Jakarta Selatan

Perihal : Gugatan Wanprestasi

Dengan Hormat,

Yang bertanda tangan dibawah ini:

Agus Purnomo, S.H. dan Albert Simorangkir, S.H., keduanya Advokat dari Kantor Pengacara Agus-Albert \& Rekan yang beralamat di Jln. Antara No. 7 Jakarta Pusat;

Berdasarkan Surat Kuasa Khusus tertanggal 15 Februari 2014 (terlampir) bertindak untuk dan atas nama serta mewakili PT. Bank Bola Dunia yang beralamat di Jln. Sudirman No. 66 Jakarta Pusat;

Untuk selanjutnya disebut sebagai Penggugat;

Dengan ini mengajukan gugatan terhadap:

Perseroan Terbatas : : PT.Manca Negara

Alamat : Jln. Sisingamangaraja No.123 Jakarta Selatan

Untuk selanjtunya disebut sebagai Tergugat;

Adapun duduk masalahnya sebagai berikut:

1. Bahwa Penggugat adalah Perseroan Terbatas yang bergerak dibidang Perbankan, yang didirikan menurut hukum Indonesia berdasarkan Akta pendirian Perseroan Terbatas No. 7 tanggal 6 November 1999 yang dibuat dihadapan Notaris Teddy Anwar, S.H. dan telah memperoleh pengesahan Menteri Kehakiman No.C-212.859.HT.01.01 tahun 2001;

2. Bahwa pada tanggal 01 Februari 2004, antara Penggugat dan Tergugat telah dibuat perjanjian uang sejumlah Rp.120 milliar kepada Tergugat, perjanjian ini dibuat dihadapan Notaris Abdul Jalil, S.H. dengan Akta Perjanjian Hutang Piutang No.100 ;

3. Bahwa dalam perjanjian tersebut Tergugat diwajibkan untuk mengembalikan seluruh pinjamannya dalam jangka waktu 2 (dua) Tahun dengan cara mencicil sebesar Rp. 5 Miliyar setiap bulannya, sebagai jaminan atas pinjaman tersebut Tergugat telah menyerahkan 2 (dua) bidang tanah berikut bangunan yang ada di atasnya yaitu:

1. Sebidang tanah seluas $1.000 \mathrm{M}^{2}$ berikut bangunan di atasnya terletak di Jln. Sisingamangaraja No.123 Jakarta Selatan sebagaimana bukti kepemilikan berupa Sertipikat Hak Milik No.31;

2. Sebidang tanah seluas $5.000 \mathrm{M}^{2}$ berikut bangunan di atasya terletak di Jln. Patmawati No. 41 Jakarta Selatan sebagaimana bukti kepemilikan berupa Sertipikat Hak Milik No.99;

4. Bahwa Tergugat hingga 1 Februari 2005 telah mengangsur sebanyak $12 x$ dengan 
jumlah seluruhnya Rp.60 Miliyar, akan tetapi setelah itu Tergugat tidak pernah melakukan kewajibannya lagi hingga batas angsuran terakhir tanggal 01 Februari 2006 sehingga kewajiban Tergugat yang belum diselesaikan mencapai jumlah Rp. 60 Miliyar;

5. Bahwa Penggugat telah berulang kali memperingatkan Tergugat untuk melunasi kewajibannya akan tetapi hingga gugatan ini diajukan Tergugat tetap tidak mengiraukan, akibatnya Penggugat mengalami kerugian setidak tidaknya berjumlah Rp. 60 milliar ditambah bunga atau keuntungan lainnya yang diharapkan;

\section{PERMOHONAN SITA JAMINAN}

Untuk menjamin apabila gugatan ini dikabulkan agar tidak sia-sia, mohon kiranya Majelis Hakim yang memeriksa Perkara ini terlebih dahulu meletakkan sita jaminan atas denda yang dijadikan jaminan, yaitu:

1. Sebidang tanah seluas $1.000 \mathrm{M}^{2}$ berikut bangunan di atasnya terletak di Jln. Sisingamangaraja No.123 Jakarta Selatan sebagaimana bukti kepemilikan berupa Sertipikat Hak Milik No.31;

2. Sebidang tanah seluas $5.000 \mathrm{M}^{2}$ berikut bangunan di atasya terletak di Jln. Fatmawati No. 41 Jakarta Selatan sebagaimana bukti kepemilikan berupa Sertipikat Hak Milik No.99;

Berdasarkan seluruh uraian tersebut di atas, mohon kiranya Majelis Hakim memeriksa dan mengadili perkara ini menjatuhkan putusan sebagai berikut:

Mengadili:

1. Menerima dan mengabulkan gugatan Penggugat untuk seluruhnya;

2. Menyatakan perjanjian hutang piutang antara Penggugat dengan Tergugat yang dibuat tanggal 01 Februari 2004 dengan Akta Perjanjian No. 100 yang dibuat dihadapan Notaris Abdul Jalil, S.H. adalah Sah dan mengikat;

3. Memutuskan, menyatakan Tergugat telah Wan Prestasi atau ingkar janji karena tidak melaksanakan isi perjanjian hutang piutang yang dibuat pada tanggal 01 Februari 2004;

4. Menyatakan sita jaminan yang telah diletakkan tersebut di atas sah dan berharga;

5. Menghukum Tergugat secara seketika paling lambat 7 (tujuh) hari sejak putusan ini diucapkan membayar secara tunai sejumlah Rp. 60 Miliyar kepada Penggugat;

6. Memutuskan, menyatakan Putusan dalam Perkara ini dapat dijalankan terlebih dahulu walupun ada upaya banding dari Pihak Tergugat;

7. Membebankan biaya Perkara kepada Tergugat.

Apabila Majelis Hakim berpendapat lain, mohon putusan yang seadil-adilnya.

Hormat Kami

Kuasa Penggugat

Agus Purnomo, $\mathrm{SH}$

Albert Simorangkir, $\mathrm{SH}$

\section{Contoh Kasus Perbuatan Melawan Hukum}

\section{Ringkasan Kasus Posisi}

Wandha Hamidah adalah seorang pengusaha yang beralamat di Jln. Karet Belakang No.8 Setiabudi, Jakarta Selatan dan berniat untuk memasarkan produksi batiknya dengan merek "Batik Kita". Dalam rangka membantu pernasaran- produk "Batik Kita", Wandha Hamidah menjalin kerja sama dengan Toni Sarumaha, yaitu seorang wiraswasta yang beralamat di Jln. Teuku Umar No. 17, Bandung, Jawa Barat, di mana kerja sama ini dituangkan dalam "Perjanjian Kerja Sama” No.7 tanggal 9 Juli 2011.

Dalam Perjanjian Kerja Sama 
tersebut disepakati bahwa Toni

Sarumaha bersedia untuk memasarkan produk "Batik Kita" di wilayah DKI Jakarta dan Jawa Barat, asalkan Wandha Hamidah berjanji tidak akan menunjuk pihak lain selain Toni Sarumaha untuk memasarkan produk "Batik Kita" di wilayah DKI Jakarta dan Jawa Barat. Di samping itu, Wandha Hamidah dan Toni Sarumaha sepakat bahwa Toni Sarumaha akan mendapat keuntungan sebesar $10 \%$ dari total omset penjualan setiap bulannya.

Pada awalnya kerja sama antara Wandha Hamidah dan Toni Sarumaha berjalan dengan lancar. Berkat usaha dan kerja kerns Toni Sarumaha dalam memasarkan produk, akhimya produk "Batik Kita" menjadi produk yang cukup dikenal dan mampu bersaing dengan produk sejenis di wilayah DKI Jakarta dan Jawa Barat. Sampai suatu ketika, pada awal April 2012 Toni Sarumaha mendapat informasi bahwa. ternyata ada pihak lain, yaitu Mardari Pedrosa, yang juga memasarkan produk "Batik Kita" di wilayah Jawd Barat. Hal ini jelas sangat mengherankan karena menurut pengetahuan Toni Sarumaha, produk "Batik Kita" hanya diproduksi oleh Wandha Hamidah dan sesuai dengan kesepakatan dalam Perjanjian Kerja Sama, Wandha Hamidah telah berjanji/sepakat tidak akan menunjuk atau menjalin kerja sama dengan pihak lain untuk memasarkan produk "Batik Kita" di wilayah Jawa Barat.

Berdasarkan keterangan dari
konsumen Berta informasi yang
diperoleh Toni Sarumaha di pasaran,

diketahui bahwa ternyata Mardani Pedrosa memperoleh produk "Batik Klita" dari Wandha Hamidah, dan diketahui pula bahwa Wandha Hamidah ternyata telah menjalin kerja sama dengan Mardani Pedrosa sejak bulan Januari 2012. Jelas dan nyata bahwa Wandha Hamidah telah melanggar kesepakatan dalam Perjanjian Kerja Sama.

Selanjutnya, Toni Sarumaha telah beberapa kali menulis surat dan meminta penjelasan kepada Wandha Hamidah. Namun ternyata Wandha Hamidah tidak memberikan ucapan atau penjelasan kepada Toni Sarumaha.

Dengan adanya itikad tidak balk dari Wandha Hamidah dalam menjalankan Perjanjian Kerja Sama tersebut maka Toni Sarumaha hendak mengajukan gugatan terhadap Wandha Hamidah. Untuk itu, Toni Sarumaha menunjuk Andre Taulani, S.H. dan Parto, S.H. darn Kamor Advokat Andre \& Parto, yang beralarnat di Jln. Kwitang Raya No. 212 Jakarta Pusat.

Pertanvaan :

Berkaitan dengan hal tersebut di atas maka saudara diminta untuk membuat Surat Kuasa Khusus dari Toni Sarumaha kepada Andre Taulani, S.H. dan Parto, S.H. dari Kantor Advokat Andre \& Parto untuk mengajukan gugatan perkara perdata tersebut.

Berdasarkan conth kasus di atas, maka contoh Surat kuasa perbuatan melawan hukum, sebagaimana yang tertera di bawah ini: 


\section{SURAT KUASA KHUSUS}

Yang bertandatangan dibawah ini:

Nama :TONI SARUMAHA

Pekerjaan : Wiraswasta

Alamat $\quad$ : Jln.Teuku Umar No. 17 Bandung

Untuk selanjutnya disebut PEMBERI KUASA ;

Dengan ini memberi kuasa kepada: Andre Taulani, S.H., 2. Parto, S.H., keduanya Advokat pada Kantor Hukum Andre \& Parto, yang beralamat Jln. Kwitang Raya No. 212 Jakarta Pusat ;

Untuk selanjutnya disebut PENERIMA KUASA;

BAIK SAMA-SAMA maupun MASING-MASING SENDIRI

KH USUS

Bertindak untuk dan atas nama serta mewakili Pemberi Kuasa GUNA MENGAJUKAN GUGATAN terhadap WANDA HAMIDAH YANG BERALAMAT DI JL. KARET BELAKANG NO.8 SETIA BUDI JAKARTA SELATAN atas PERBUATAN MELAWAN HUKUM karena tidak melaksanakan isi PERJANJIAN KERJA SAMA YANG DIBUAT PADA TANGGAL 09 JULI 2011 melalui Kepaniteraan PENGADILAN NEGERI JAKARTA SELATAN.

Selanjutnya penerima kuasa diberikan segala hak untuk melakukan tindakan hukum yang dianggap perlu dan berguna untuk kepentingan hukum pemberi kuasa sebagai Penggugat;

Kuasa ini diberikan dengan HAK SUBTITUSI dan HAK RETENSI;

JAKARTA, 15 FEBRUARI 2014

PEMBERI KUASA

PENERIMA KUASA

Meterai 6000

Toni Sarumaha

1. Ande Taulani, S.H.

2.Parto SH 


\section{Contoh Gugatan Perbuatan Melawan Hukum}

Jakarta 17 Februari 2014

Kepada Yth:

Ketua Pengadilan Negeri Jakarta Selatan

Jln. Ampera Raya No. 136

di- Jakarta Selatan

Perihal : Gugatan Perbuatan Melawan Hukum

Dengan Hormat,

Yang bertanda tangan di bawah ini:

Andre Taulani, S.H dan Parto, S.H., keduanya Advokat dari Kantor Advokat Andre \& Parto beralamat di Jln. Kwitang Raya No. 212 Jakarta Pusat, berdasarkan surat kuasa khusus tertanggal 15 Februari 2014 (terlampir) bertindak untuk dan atas nama serta mewakili:

$\begin{array}{ll}\text { Nama } & : \text { Toni Sarumaha } \\ \text { Pekerjaaan } & : \text { Wiraswasta } \\ \text { Alamat } & : \text { Jln. Teuku Umar No. } 17 \text { Bandung }\end{array}$

Untuk selanjutnya disebut sebagai Penggugat;

Dengan ini mengajukan gugatan terhadap:

Nama : Wanda Hamidah

Pekerjaan : Wiraswasta

Alamat $\quad$ : Jln. Karet Belakang No. 08 Setia Budi Jakarta Selatan

Untuk selanjtunya disebut sebagai Tergugat;

Adapun duduk masalahnya sebagai berikut:

1. Bahwa antara Penggugat dengan Tergugat pada tanggal 09 Juli 2011 telah membuat Surat Perjanjian Kerjasama yang pada pokoknya bahwa Penggugat ditunjuk oleh Tergugta untuk memasarkan hasil produksi kain batik dengan merek "Batik Kita" di wilayah DKI Jakarta dan Jawa Barat dan Penggugat adalah satu-satunya yang berhak untuk memasarkan produk "Batik Kita" untuk wilayah DKI Jakarta dan Jawa Barat dengan memperoleh keuntungan sebesar $10 \%$ dari total nilai penjualan setiap bulan (vide Bukti P-1);

2. Bahwa ternyata sekitar bulan April 2012 Penggugat mengetahui ada pihak lain (yaitu Sdr. Mardani Perdrosa) yang juga ikut memasarkan produk" Batik Kita" di wilayah Jawa Barat berdasarkan penunjukan oleh Tergugat;

3. Bahwa perbuatan Tergugat yang telah menunjuk pihak lainnya (Mardani Perdrosa) untuk memasarkan produk "Batik Kita" di Wilayah Jawa Barat adalah perbuatan melawan Hukum karena bertentangan dengan Perjanjijan Kerjasama yang dibuat 
oleh Penggugat dengan Tergugat pada tanggal 09 Juli 2011;

4. Bahwa oleh karena itu Penggugat telah berulang kali mengirimkan surat untuk meminta penjelasan kepada Tergugat mengenai adanya pihak lain yang turut memasarkan produk "Batik Kita" di wilayah Jawa Barat, akan tetapi Tergugat tidak pernah memberikan tanggapan atau penjelasan kepada Penggugat;

5. Bahwa akibat dari adanya pihak lain yang turut memasarkan produk "Batik Kita” di wilayah Jawa Barat telah menimbulkan kerugian bagi Penggugat secara materil tidak kurang dari Rp. 500.000.000,- (lima ratus juta rupiah) dan apabila Tergugat tidak memutuskan penunjukan kepada Mardani Pedrosa untuk memasarkan produk "Batik Kita" di wilayah Jawa Barat" akan terus mengakibatkan kerugian secara materil kepada Penggugat;

Berdasarkan seluruh uraian tersebut di atas mohon kiranya Majelis Hakim Pengadilan Negeri Jakarta Selatan yang memeriksa dan mengadili perkara ini berkenaan untuk memutuskan sebagai berikut:

Mengadili:

1. Menerima dan mengabulkan gugatan Penggugat untuk seluruhnya;

2. Menyatakan Perjanjian Kerjasama yang dibuat oleh Penggugat dengan Tergugat pada tanggal 09 Juli 2011 adalah sah dan mengikat;

3. Memutuskan menyatakan Tergugat telah melakukan perbuatan melawan hukum yaitu tidak melaksanakan isi Perjanjian Kerjasama tanggal 09 Juli 2011;

4. Menghukum Tergugat untuk membayar ganti rugi kepada Penggugat sebesar Rp. 500.000.000,- (lima ratus juta rupiah) secara tunai selambat-lambatnya 7 (tujuh) hari setelah putusan dalam perkara ini diucapkan;

5. Memutuskan menyatakan putusan dalam perkara ini dapat dijalankan terlebih dahulu walaupun ada upaya banding dari pihak Tergugat;

6. Membebankan biaya perkara kepada pihak Tergugat.

Apabila Majelis Hakim berpendapat lain mohon dapat dijatuhi putusan yang seadiladilnya.

Hormat Kami

Kuasa Penggugat

1. Andre Taulani, S.H.

2. Parto, S.H.

\section{SIMPULAN}

Dalam praktek tidak ada pedoman yang baku tentang teknik dalam menyusun surat khuasa khusus maupun gugatan, hal itu disebabkan karena masalah hukum itu selalu bervariasi, namun terlepas dari hal dimaksud dalam menyusun surat kuasa khusus maupun gugatan seorang Advokat harus: (1). mempunyai cara berpikir distinktif; (2). menguasai hukum materil dan formil sebagai dasar hukum; (3). mampu mengklasifikasi masalah hukum; (4). mampu membuat narasi bahasa secara singkat, padat serta mencakup baik mengenai posita maupun petitumnya; dan (5). berpikir taktis serta teliti. 


\section{DAFTAR PUSTAKA}

Lemek, Jeremias, Penuntun Membuat Gugatan, Liberty, Yogyakarta,1993.

Peradi, Kitab Advokat Indonesia, Jakarta: Dewan Pimpinan Nasional Perhimpunan Advokat Indonesia, 2007.

Harahap, M.Yahya, Hukum Acara Perdata tentang Gugatan, Persidangan, Penyitaan, Pembuktian dan Putusan Pengadilan, Sinar Grafika, Jakarta, 2005.

Prinst, Darwan, Strategi Menyusun dan menangani Gugatan Perdata, PT.Citra Aditya Bakti, Bandung, 1996.

Wiguna, M. O. C. (2018). Surat Kuasa Membebankan Hak Tanggungan Dan Pengaruhnya Terhadap Pemenuhan Asas Publisitas Dalam Proses Pemberian Hak Tanggungan. Jurnal Legislasi Indonesia, 14(4), 439-446.

Nursolih, E. (2019). Analisis Penyusunan Surat Gugatan. Jurnal Ilmiah Galuh Justisi, 7(1), 87-97.

Nazra, W. A. (2021). Pengertian Gugatan dan Bentuk Gugatan dan Tuntutan Di Pengadilan Tata Usaha Negara. 